\title{
Designs of Kings and Farmers: Landscape Systems of the Greater Angkor Urban Complex
}

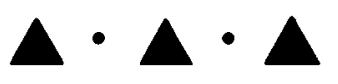

SCOTT HAWKEN

\section{ANGKOR AND ITS DISPERSED SETTLEMENT PATTERN}

Greater Angkor was the capital of the Khmer Empire from the ninth to the fourteenth centuries A.D. The rulers of Angkor left behind magnificent temples, along with extensive, centrally planned landscapes and massive urban complexes. The Greater Angkor landscape also contains a decentralized planning tradition, largely unrecognized in research to date. This article addresses the different scales of economic landscapes at Greater Angkor, from massive irrigated rice-field superstructures to smaller patches of fields organized around local temples and ponds. Contrary to widely accepted views, the design of extensive cultural landscapes does not require the presence of an elite controlling authority or the guidance of a communally conceived plan (Johnston 2005). Within Greater Angkor, the design of extensive landscapes often occurred at the local level, and most likely involved local traditions rather than abstract, centrally approved plans.

The relationship between centralized and decentralized planning traditions is investigated, using a topographic classification of the landscape based on extensive mapping from remote sensed imagery and fieldwork conducted from 2007-2010. Covering about $1000 \mathrm{~km}^{2}$ of rice fields, and including 22,000 km of rice-field bunds, the topographic classification of the rice-field systems reveals two very different ways of building: these two systems are best described as coaxial systems and cardinal systems. Both suggest dramatically different development models and socioeconomic frameworks. The two different and extensive development processes had a lasting physical impact on the resulting landscapes, which are still actively used by farmers today. This article presents evidence of distinct central and local plans, as well as more complicated examples where both central and local plans seem to have influenced landscape design. Illustrated examples of centrally and locally planned landscapes demonstrate this premise. 
The settlement pattern of Angkor has been comprehensively mapped in the last two decades (Evans et al. 2007). Before that, research focused on the extraordinary temple architecture and epigraphic tradition. There were a few exceptions, such as the extensive reconnaissance and mapping work of Lunet de Lajonquière (1902-1911) and settlement studies of metropolitan Angkor by B-P. Groslier (1979), that emphasized geographic context and landscape. Only with the mapping work of Pottier (1999) and Evans (Evans et al. 2007), combined with Fletcher's (2009) theoretical settlement approach, has our understanding of Angkor convincingly shifted from merely knowledge of its monuments to an integrated picture of its urban landscape.

Landscape spaces are a significant component of all cities, but landscape assumes even more significance for Greater Angkor. Medieval Greater Angkor and Khmer cities are generally part of a Southeast Asian urban tradition that favors low density, dispersed settlement patterns. Such cities consist of clusters of urban elements in a dispersed polycentric pattern, with vast stretches of open space between monuments and architectural elements. This pattern of urban development can also be seen in other medieval and ancient geographic contexts, such as Sri Lanka and Central America, but it is perhaps best demonstrated in Southeast Asia.

Greater Angkor presents an extensive and incredibly well-preserved landscape palimpsest, and is the best example worldwide of a dispersed urban complex from the medieval period. Over the past two decades, various elements of this palimpsest have been recovered using remote sensing technology. These elements include large, medium, and small temples; ponds; canals; roads; embankments; and rice fields. Most of the architecture has perished, and what remains are simple, earthen topographic features. Temple and other architectural elements are only part of an urban complex that, to date, has been best understood through a hydraulic infrastructure that integrated settlements into a vast hydraulic territory.

The most common and extensive of these elements are medieval rice fields. Except for a few key articles and reports by Pottier (2000a, 2000b) and Bâty (2005), along with more general overviews by Van Liere (1980, 1989) and Groslier (1974, 1979), rice fields have been overlooked as a source of information, compared to other elements. This is despite the fact that rice fields formed both the economic and structural foundation for the metropolis of Greater Angkor.

Using a combination of remote sensing and morphological analysis, Pottier (1999, $2000 a$ ) has established the contemporaneity of rice fields with Khmer temples and Angkor's urban complex. The integral association between rice field, temple, and settlement sites has been further demonstrated by the extensive excavations carried out by Bâty (2005) as part of a rescue archaeology program associated with the development of Siem Reap International Airport: these are the most extensive excavations within Greater Angkor to date. The excavations show the stratigraphic coherence of whole rice-field systems and associated topographic features, such as trapeang (ponds) and prasat (temples) (Bâty 2005).

The study of field systems is the study of spatial regularity (Chouquer 2000; Chouquer et al. 1987; Chouquer et al. 1991). Our knowledge of the principles of Angkorian planning comes almost completely from the material record. Unlike the Roman examples studied by Chouquer and colleagues (1987), there is little explicit textual evidence of the units that were used when setting out Angkorian fields. Only two 
Angkorian plans have been located, as engravings on stone temples. The archaeological approach undertaken at Angkor therefore contrasts with the epigraphic emphasis of studies in the classical world. Through an iterative process, it was found that the most effective way of understanding the structure of the Angkorian landscape was through analysis of the regular orientation of landscape elements. Despite the central place of rice in Southeast Asian life, this archaeological study is the first to systematically examine the relationship between rice-field morphology and large-scale settlement patterns in Southeast Asia.

\section{MAPPING RICE-FIELD SYSTEMS}

This article presents a completed program of research, based on the initial observations of Pottier and Bâty and the analysis and classification of rice-field systems evident in remote sensed imagery. Research completed by this author involved comprehensive mapping, classification, and analysis of the archaeological rice-field morphology of Angkor.

The landscape was first analyzed at the scale of an individual feature: the rice-field bund. The large-scale patterning of rice-field bunds was then investigated as an aggregated landscape of localized patches. These patches form coherent systems that can be read at the scale of the broader landscape across the alluvial and lacustrine plains of Tonle Sap, the largest lake in Southeast Asia, which forms the geographic context for Angkor.

The rice fields were mapped in ESRI's ArcMap with the intent of seamlessly integrating the new mapping layers with existing work by Evans and colleagues (2007) and Pottier (1999). Time spent mapping rice-field bunds in a GIS lab was combined with several seasons of fieldwork, between 2007 and 2009, that were devoted to selectively checking mapping work and understanding the ecological, topographic, and cultural dimensions of the landscape. Three major types of data were gathered in the field: 1) information about archaeological features, 2) topographic and ecological data, and 3) ethnographic data.

The research analyzed rice-field landscapes using two methods, each of which corresponds to a different way of representing rice fields. Rice-field landscapes have been represented as: 1) networks of polylines and 2) aggregated patches of pixels. This study's process for recovering rice-field patches from the archaeological record involved interpreting rice-field boundaries as linear elements, which were represented in the GIS as polylines. These polylines were then classified according to orientation and other morphological characteristics. After this classification, the polylines were aggregated and represented as a raster with each pixel representing $40 \mathrm{~m}^{2}$ $(20 \mathrm{~m} \times 20 \mathrm{~m}$ to $40 \mathrm{~m} \times 40 \mathrm{~m}$ is the typical range in rice-field size), thereby generating patches having an area and a perimeter. The transformation of the data into a raster made it possible to subject that data to additional types of analyses. Representing landscapes as cell-based rasters is common within the discipline of landscape ecology. Consequently, this study was able to draw on a wealth of precedents. The proliferating literature on landscape ecology and urban landscapes was reviewed to select the appropriate metrics for analyzing the landscape themes in question. Landscape metrics can be used to quantify the composition, configuration, and structure of both urban and natural landscapes (McGarigal et al. 2002; Turner 2005). 


\section{CLASSIFYING RICE-FIELD PATCHES AND SYSTEMS}

Within several disciplines, and especially within landscape ecology, patches form the basis, or building blocks, for categorical maps (McGarigal et al. 2002). Patches of the same class form landscape systems. Where these patches are contiguous, these patches can form a matrix within which other isolated patches are embedded. Patches can be characterized as a specific land use (e.g., forest, rice field) or can be classified in terms of properties of the land use (i.e., quality of the forest) or the spatial or compositional characteristics of a land use (i.e., species composition of a forest, geometric properties of rice-field networks). The mean, modal, central, or maximum value of a variable may be calculated for a patch, or a measure of internal heterogeneity with respect to that variable may be used. In most applications of the technique, once patches have been established, the heterogeneity within a patch is ignored so that focus can be directed to the relationships between patches (McGarigal et al. 2002).

In this study, rice-field landscapes are made up of one or more classes of rice-field patch. By contrast, a rice-field system is comprised of a single class of rice-field patch. The patches within a system can vary, but must have common morphological properties. Rice fields can be classified by automatic quantitative analysis (i.e., according to orientation) or by conducting a more in-depth morphological analysis involving both automatic and manual classification techniques. Both of the above classification methods are used in this study.

Although the variety of rice-field systems within Greater Angkor is diverse, the sampling of broad enough areas throughout Greater Angkor permitted the categorization of field systems into major types. Each type of field system can be further divided into subsystems (Fig. 1). Seven major field-system types were identified by a combination of automatic and manual morphological analysis. These consist of:

1. Orthogonal grids of rectilinear systems

2. Orthogonal grids of square systems

3. Coaxial systems

4. Fan systems

5. Radial systems

6. 1 ha Khmer Rouge systems

7. Aggregate systems

This article focuses on the orthogonal grid and coaxial field systems, which make up the bulk of the landscape of Greater Angkor. These two systems are described below.

GREATER ANGKOR'S TWO MAJOR RICE-FIELD SYSTEMS: ORTHOGONAL AND COAXIAL

The defining image of Angkor is of an immense urban complex of cardinally oriented temples and infrastructure. In satellite images, Angkor's large, cardinally oriented baray (artificial reservoirs), canals, and prasat (temples) testify to this. Dagens $(2003: 165)$ states: "Il apparaît que l'orientation cardinal vers l'est, est la norme khmère par excellence et pourrait-on dire la 'signature' khmère dans l'organisation ou la réorganisation d'un site [It appears that the cardinal orientation to the east is the Khmer standard par excellence and arguably the Khmer 'signature' in the organization or reorganization of a site]." Rice fields are an integral part of this cardinal landscape. Within this cardinal landscape there are two subtypes of fields: square and rectangular. 
1.0

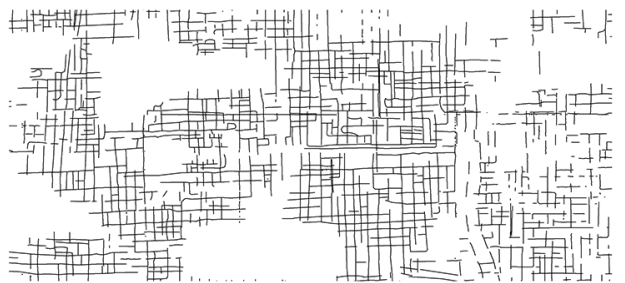

3.0

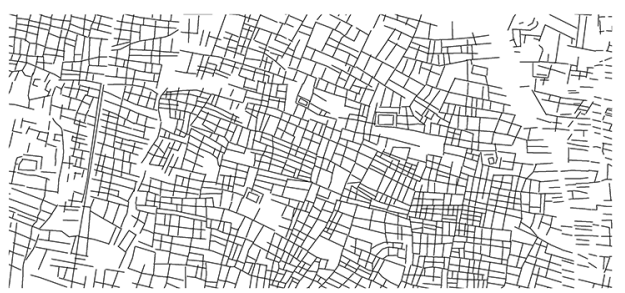

5.0

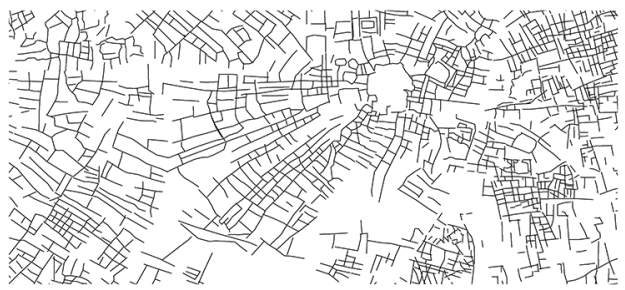

2.0

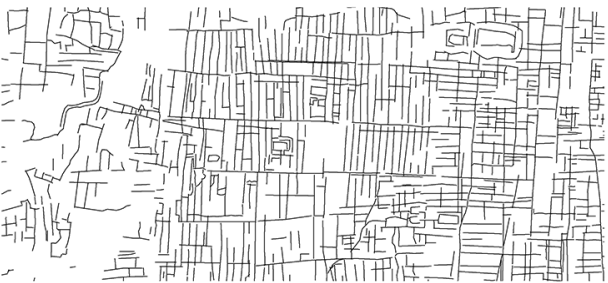

4.0

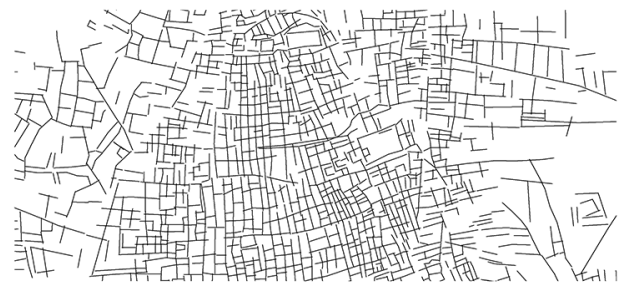

6.0

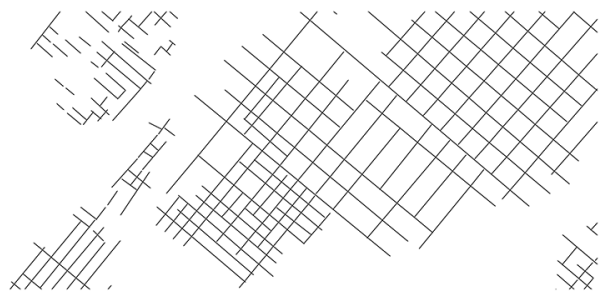

$\begin{array}{lll}0 & 500 \quad 1.000 \quad 2.000 \text { Meters }\end{array}$

Fig. 1. Six major rice-field system types within Greater Angkor: 1) orthogonal square system, 2) orthogonal rectilinear system, 3) coaxial system, 4) fan system, 5) radial system, 6) Khmer Rouge system. (Data from Hawken 2011.)

Square-field systems consist primarily of fields that do not have a dominant axis, as all of each field's sides are of equal length. However, the system as a whole may have directionality: for example, it may be longer than it is wide or it may be given direction by intermediate features such as canals or embankments. Orthogonal, cardinally aligned field systems, consisting of squares 30 to $40 \mathrm{~m}$ wide, have been closely associated with Angkor ever since such systems became evident from aerial reconnaissance conducted by Goloubew (1936). Around monuments such as Phnom Bakheng and Chau Srei Vibol, they are explicitly described by Groslier (1952, 1998 [1956]) and Bosselier (Evans 2007:68) as being associated with medieval hydraulic infrastructure. Pottier $(2000 b)$ and Van Liere $(1980,1989)$ suggest that Khmer field systems across Mainland Southeast Asia consist of grids of small square fields that are calibrated to the microtopography and carefully engineered according to hydraulic management principles. At Angkor, Pottier confirmed these assertions through investigations south of the West Baray (2000b; also see Pottier 1993, 2000a). Square rice fields commonly form clusters around temples, shrines, and other settlements, thus forming cultural complexes that are both spatially and temporally associated. 
A modern version of a square-field system is the Khmer Rouge 1 ha system (Martin 1981). The very uniform size of Khmer Rouge fields makes such fields easily distinguishable from Angkorian fields. Found throughout Greater Angkor, Khmer Rouge fields are always 1 ha squares. Khmer Rouge field systems are divided into four-field blocks by small canals (Martin 1981). The Khmer Rouge systems around Siem Reap are aligned with the major roads and the UTM grid set out on Vietnamese maps of the time. This is common throughout Cambodia (Pottier pers. comm. 2010). Despite the very large size of Khmer Rouge field systems, they are disappearing rapidly because farmers prefer smaller fields and see no need for the many canals that form part of the Khmer Rouge systems. Farmers today prefer to use the space taken up by canals to cultivate rice.

Like square orthogonal grids, rectilinear field systems can be found clustered around temples in small patches. Rectilinear fields have two clear axes, but unlike square-grid systems, one axis dominates. Rectilinear fields such as the grid found just to the east of Angkor Thom and above the West Baray are found in formal hierarchical systems, but they can fuse with coaxial systems. Modern flood-recession rice fields are situated along the shores of the Tonle Sap and consist of long, narrow strips. The walls of such fields are usually slight. They are not needed to retain water, because in flood-recession rice fields the water table is very close to the surface. These modern fields are irrigated with water from thamnup (reservoirs) that trap the receding waters of Tonle Sap.

In contrast to orthogonal systems, which have two clear axes, coaxial systems are defined (Fleming 1987, 1989) as a series of fields laid out according to a single dominant axis of orientation. Even though the axis can curve or change direction, most of the major boundaries of the field system should be parallel to one another. Field bunds comprise either coaxial boundaries aligned with the major axis or transverse boundaries that run at right angles to the major axis. Frequently the transverse boundaries are organized in a staggered pattern. The degree of infilling of transverse field boundaries in such systems is also variable, and the fields are usually rectangular rather than square.

In contrast to an orthogonal grid that has one major orientation, a coaxial system may include a range of orientations. For example, the axis may curve or shift dramatically according to the contours of a hill. So while the term coaxial can refer to orthogonal systems, it is more frequently used where a coherent system is organized according to a single axis that changes. This is the sense of the term used in this study. Coaxial systems vary greatly in size and are the most common type of field system. They are found throughout Greater Angkor, being especially prevalent on the periphery, where they form very large matrices of many thousands of hectares. As a large coaxial system has an axis that shifts throughout the system, such large continuous systems can be broken down into many patches by defining patch boundaries where shifts in orientation occur. This is achievable by applying automatic orientation classification methods in a GIS. Coaxial field systems are usually associated with ponds and mounds and, less frequently, temples.

Coaxial systems have been investigated by the landscape archaeologist Andrew Fleming (1989:63-82) in his research in the United Kingdom. Fleming makes the point that it is debatable how many boundaries have to be parallel to one another, and how large an area they should ideally cover, to qualify as a coaxial system. He suggests 100 ha as the minimum qualifying area, but as most systems are only partially preserved, such figures need to be qualified. These systems are often very large. Two of 
the most extensive have been found in Dartmoor, Devon, in southwestern England. Each system covered over 3000 ha, and may once have been as extensive as 4500 ha (Fleming 1989:63). Fleming states that later Roman linear features, such as roads or other field systems, are superimposed upon some coaxial systems in the United Kingdom. They can therefore be given relative dates. Few have absolute dates, due to the wide area encompassed by such systems and the variety of features associated with the systems. This may change in the future, since many have only recently been located and published.

The United Kingdom precedent is particularly applicable to the coaxial systems at Angkor in that both systems relate to the contours of the landscape. Following are two case studies from Greater Angkor's landscape: first, a case study emphasizing the orthogonal systems, and second, a case study emphasizing the coaxial systems.

\section{CHARACTERIZING GREATER ANGKOR'S CARDINAL LANDSCAPE}

The tenth-century A.D. urban complex surrounding the temple pyramid of Pre Rup is associated with one of the cardinal grids of Greater Angkor that is clearest in remote sensing imagery (Fig. 2). The composition of the complex seems to have followed the same standards as those applied to the ninth-century A.D. complex surrounding the Bakong pyramid at Roluos. The Pre Rup pyramid, the East Baray, the East Mebon, and the site near Trapeang Khmoch (which is probably a palace or royal complex) all exhibit spatial relationships that are similar to those of equivalent structures at Roluos. This similarity suggests a continuous urban tradition. Roluos' hydraulics and urban planning are sufficiently like those of the other complexes for us to categorize Roluos as an Angkorian city, rather than as the pre-Angkorian city it is conventionally said to be (Pottier 1999: 183-199).

Like the Bakong complex, the tenth-century A.D. urban complex surrounding Pre Rup is open, dispersed, and without any enclosing walls. Like those of the Roluos Baray or Indratataka, the immense $1800 \mathrm{~m} \times 7000 \mathrm{~m}$ dykes of the East Baray play a central role in the spatial composition of the Pre Rup complex, ordering the placement of temples, shrines, and rice fields (Pottier 1999:176-182). Within the large areas adjacent to the massive reservoir's south bank are impressive rice fields that indicate the impact of hydraulic superstructures on rice cultivation, even when such structures are in disrepair today. Rather than enclosing streets, houses, and other built structures in the way that conventional city walls do, the hydraulic dykes probably acted as the foundations for considerable development in the same way that the embankment running through the East Baray supports the village of Predak today. The dykes of the East Baray are also integrated with the structures of Pre Rup's urban complex via a range of intermediate features. Causeways and channels connect the giant dykes of the baray with mounds, ponds, and other topographic features of the complex, including Prasat Ong Mong ID53004, Pre Rup ID53800, and Prasat Komnap ID53003 (Pottier 2003). The causeways show that the baray was functionally integrated with the life of the city in more than hydraulic ways (Pottier 1999:191).

The Pre Rup complex is enveloped by a tight grid of cardinally oriented rice fields. This grid extends alongside almost the whole length of the East Baray's south embankment. Among Pre Rup's fields, it is possible to distinguish a zone that is particularly dense and very regular. This zone is comprised of nearly square parcels that are each between $35 \mathrm{~m}$ and $40 \mathrm{~m}$ wide, particularly in the area to the southeast of Pre Rup around the water axes of Boeng Ta Srei ID100395. The grid covers a rectangular 


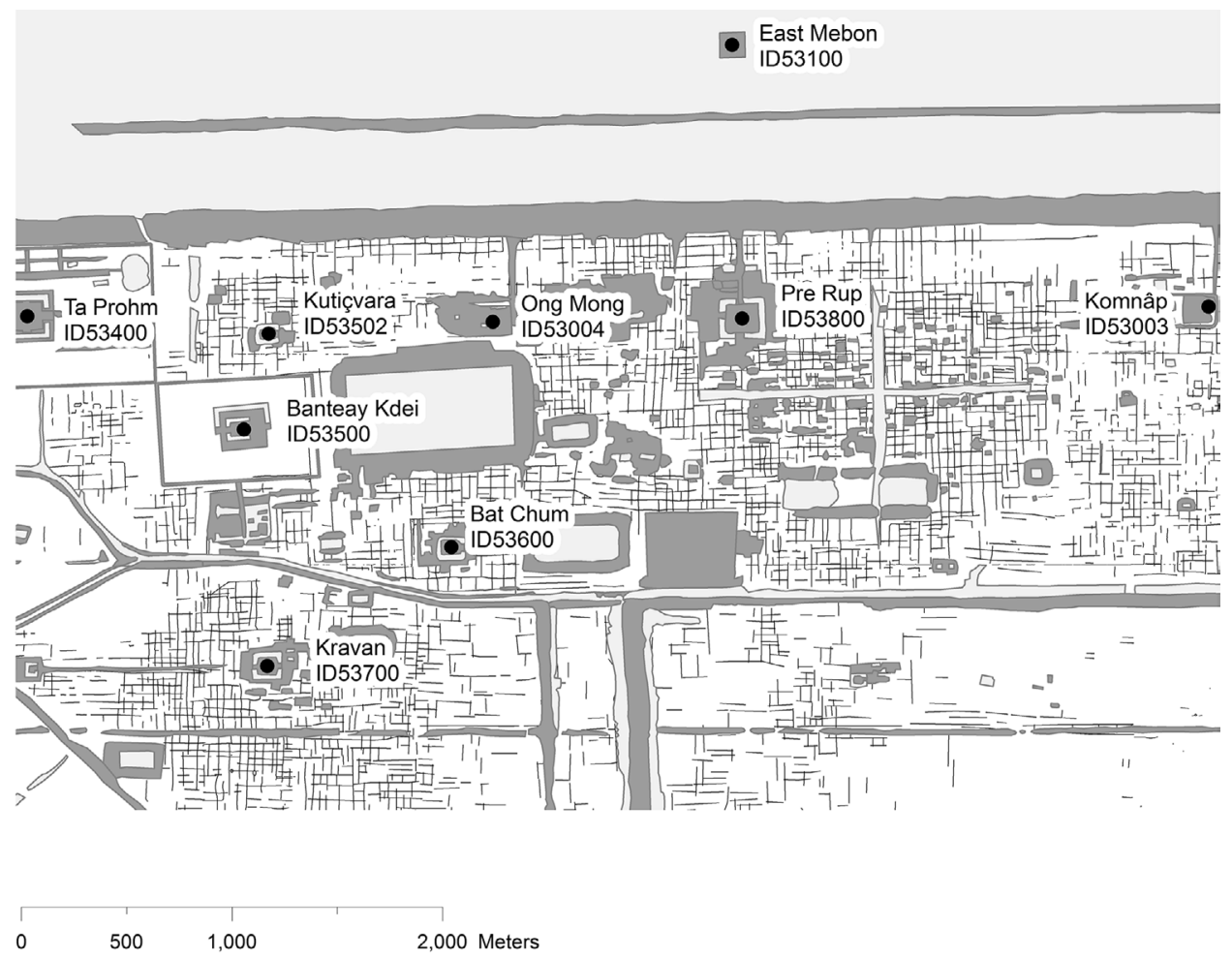

- Site ID

$\square$ Pond, Moat or Reservoir

Embankment or Mound

- Orthogonal Rice-field Systems

Fig. 2. State temple rice-field system. Remote sensing imagery reveals that the tenth-century A.D. urban complex surrounding the temple pyramid of Pre Rup is associated with one of the cardinal grids of Greater Angkor. (Data from Pottier 1999.)

area of roughly $1700 \mathrm{~m}$ by $1800 \mathrm{~m}$, or about 300 ha. Strictly orthogonal, the grid forms a coherent unit with major temples from several periods. Monuments built by Rajendravarman II and Jayavarman VII are embedded within the grid (Pottier 1999: 188). The grid's strong spatial association with major Angkorian features of the tenth century overwhelmingly suggest it is Angkorian (Pottier 1999:188). It is difficult to give a more specific date for the establishment of the grid except to say that it was functional during the late tenth-century rule of Rajendravarman II. However, the grid was probably constructed before then, as a part of works associated with the East Baray. The grid presents a definitive example of a state-designed rice-field system closely integrated with state infrastructure and temples.

\section{Local Angkorian Temples and Cardinal Rice Fields}

In contrast to the large state settlements around Pre Rup, many of the cardinal settlements of Greater Angkor consist of small patches around humble local settlements. 
Many of these patches are configured around small local temples that have progressively been catalogued throughout the twentieth century. For example, in 1931, Marchal located local temples such as Kuk Talek ID58902 (1931a:159-160) and Prasat Kok Pongro ID58905 (1931b:187-190) to the south of Pre Rup. Years later, B.-P. Groslier added many other local sites to the register, including the site of Kuk Chak ID100411, where he also located a new inscription (Cœdès 1966:141). Since rice fields were not mapped in these early inventories, such sites were represented as points within the landscape rather than as landscape complexes involving rice fields. Nevertheless, shrines and temples were clearly the nodes around which rice fields were generated.

A high density of small local temples are located near Central Angkor, to the south of Pre Rup. These local temples are a useful starting point for differentiating the sometimes subtle variation between rice-field grids. The clusters of tenth-century A.D. temples to the south of Greater Angkor are frequently associated with well-defined cardinal grids. Individual cardinal patches are depicted in Figure 3. Sometimes temples with cardinally oriented rice-field grids existed as isolated patches surrounded by a matrix of oblique grids, or by scrubland. More commonly, several cardinal grids, each associated with a different shrine, are integrated with one another. Vat Kok Chan Reangsei ID100404 and Trapeang Boeng Phlou ID100407 present such an integrated example.

The cardinal rice-field patch surrounding the shrine complex of Vat Kok Chan Reangsei consists of rectilinear fields, each oriented north-south and measuring $75 \mathrm{~m} \times 35 \mathrm{~m}$ (a somewhat unusual size). This patch extends to the east, where it melds with the grid of square $70 \mathrm{~m}$ wide fields arrayed around Trapeang Boeng Phlou 100407. Between the two shrines lies a zone in which the grid associated with each shrine adjusts to the dimensions of the other grid, making it difficult to clarify relative order of construction of the grids. The rice fields date from the early tenth century A.D. at the latest, because linear feature ID100791, which extends from central Angkor to Roluos, is superimposed upon the two-shrine rice-field network.

Prasat Kuk Talek ID58902 is significant in the area south of the East Baray, both because of its sandstone and brick shrines and because it sits within a large patch of rice fields that encompasses several trapeang. This patch could be said to constitute a suburb. Located by Marchal in 1931, Prasat Kuk Talek is a large and now completely ruined multishrine complex containing numerous carved sandstone fragments, including colonnettes, large $60-\mathrm{cm}$ stone finials, a yoni, and a foundation box. It presents an example of a site with a grid that shows considerable variation. The site includes several large rectangular trapeang, several smaller ponds, and an east-facing Angkorian temple within a horseshoe-shaped moat. This temple originally consisted of three small brick shrines. Development of the site appears to have been multiphased: rice-field patterns around the site support this premise. A small irregular grid, consisting of fields that each measure around $30 \mathrm{~m} \times 40 \mathrm{~m}$, lies immediately adjacent to the temple. Farther from the temple, the fields are larger, each measuring approximately $70 \mathrm{~m} \times 70 \mathrm{~m}$. The Kuk Talek grid extends north until it meets an east-west-running feature that separates the Kuk Talek grid from that of trapeang ID100409.

The diversity within this single cardinal patch illustrates the variation and innovation used throughout Angkor in the integration, development, and extension of ricefield systems. The above analysis suggests that classifying rice fields according to their orientation is a robust strategy for defining rice-field systems. Once a system has been 


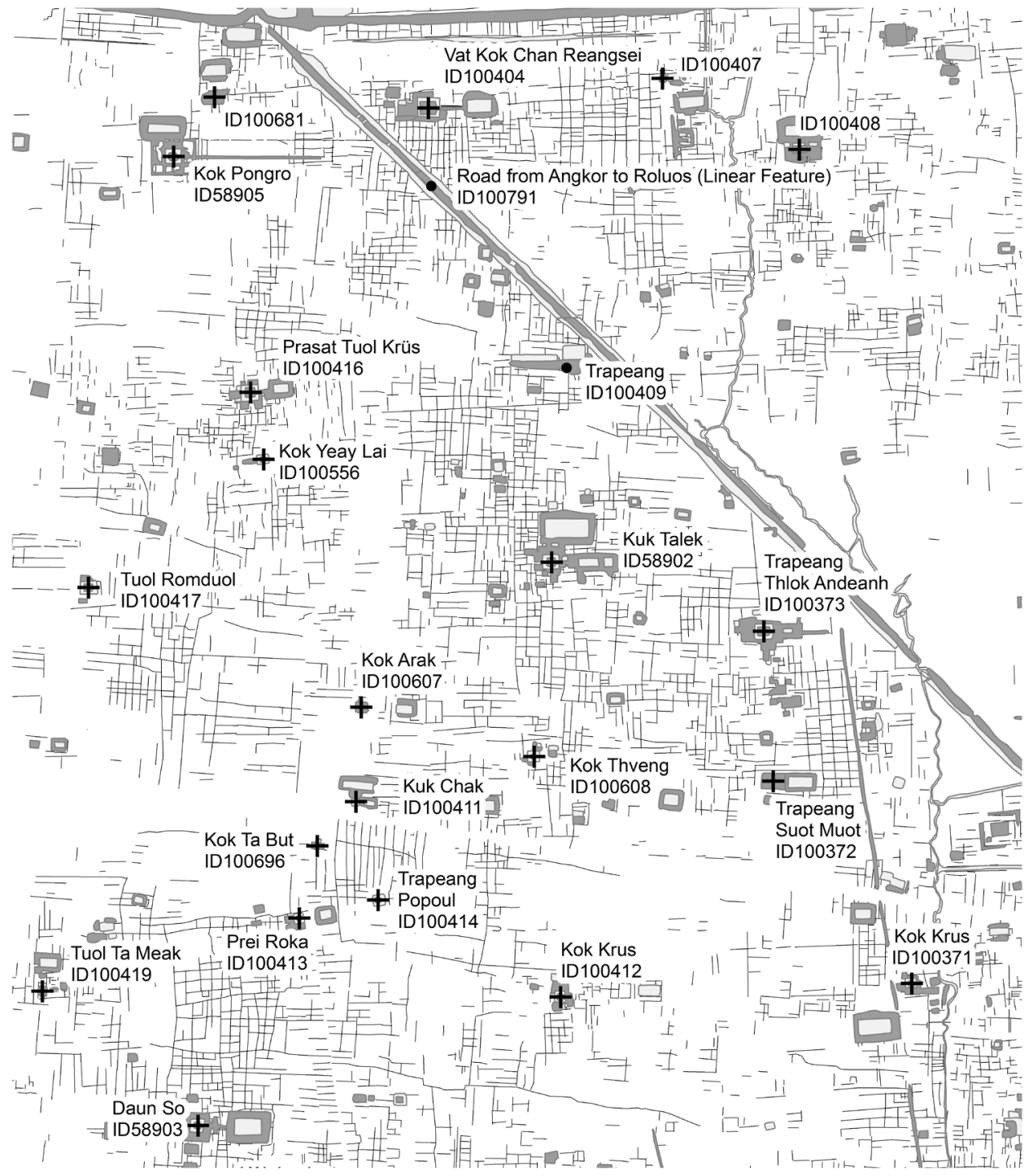

$0 \quad 500 \quad 1,000 \quad 2,000$ Meters

- Site ID

+ Temples

Pond or Reservoir

Embankment or Mound

- Orthogonal Rice-field Systems

Fig. 3. Local temple / rice-field associations. Individual rice-field patches around local temples form a large matrix of orthogonal and cardinally orientated rice-field systems south of the East Baray. (Data sources: Evans 2007; Hawken 2011; Pottier 1999.) 
defined, the study of rice-field size and shape can inform fine-grained analysis. The clusters of small local temples south of the Pre Rup complex present clear examples of local temples with independent, locally generated grids integrated to form a larger, if fragmented, rice-field system.

\section{Orthogonal Rice-Field Landscapes Considered at the Metropolitan Scale}

Considered together, the local and state temple landscapes clustered to the south of the East Baray form a series of contiguous patches that coalesce into an elongated matrix of cardinal fields. This matrix extends south from the East Baray all the way to the floodplain of the Tonle Sap (Fig. 4). The matrix has an area of about 6500 ha, making it the largest cardinal matrix in Greater Angkor.

The consistent orientation of rice fields within this cardinal matrix, the tendency of these cardinal rice fields to occur in clusters, and their correlation with large-scale Angkorian hydraulic features such as the East Baray and the channelized Roluos River together suggest that the matrix was oriented in relation to regional topographies. Just as immense baray and linear embankments have been planned within a regional framework, rice fields as the smallest spatial unit within the Angkorian metropolis, have seemingly been laid out in accordance to a regional framework, even if they were constructed at different times and by independent local authorities.

Although patches within these matrices give indications of having been planned within a regional framework, they vary considerably both in the size of their rice fields and in their configuration with respect to local topographic conditions. It seems that while the local temples and rice-field systems of these patches developed without state intervention, they nevertheless emulated common planning standards. It is also possible that the elongated matrix of fields, extending south from Pre Rup, evolved in response to the provision of irrigated water by the state and therefore had a functional rather than formal relationship with centralized authority.

\section{CHARACTERIZING GREATER ANGKOR'S COAXIAL LANDSCAPE}

In contrast to central Angkor, coaxial rice-field systems dominate the landscapes at the periphery of Greater Angkor and along the flood zone of Tonle Sap. One such system is located to the north of the West Baray (Fig. 5). Here, the coaxial system is associated with a dense distribution of ponds and small, obliquely oriented local temples. A few large temples, such as Neam Rup, are also associated with the system. The relatively small number of large temples and the presence of a dense, repetitive pattern of small, obliquely aligned ponds characterize the most coherent parts of the system, suggesting a local rather than a state scale of settlement in this area.

The coaxial grid largely coincides with a southwest-flowing tracery of meandering streams and palaeochannels that emerge from the adjacent low, regrowth forest to the northeast. According to recent remote-sensing analysis of the palaeolandscape, some of these streams have been present since the medieval period (Evans and Traviglia 2012; Traviglia 2010). However, most of the streams are ephemeral overflows that are difficult to detect in remote-sensed images and only periodically apparent on the ground. The rice fields within this oblique network are extremely well defined by thick hedges that can be up to $5 \mathrm{~m}$ wide and $4 \mathrm{~m}$ high. Each hedge has a bund as its base. Local farmers know routes between seemingly impenetrable barriers of thorny 


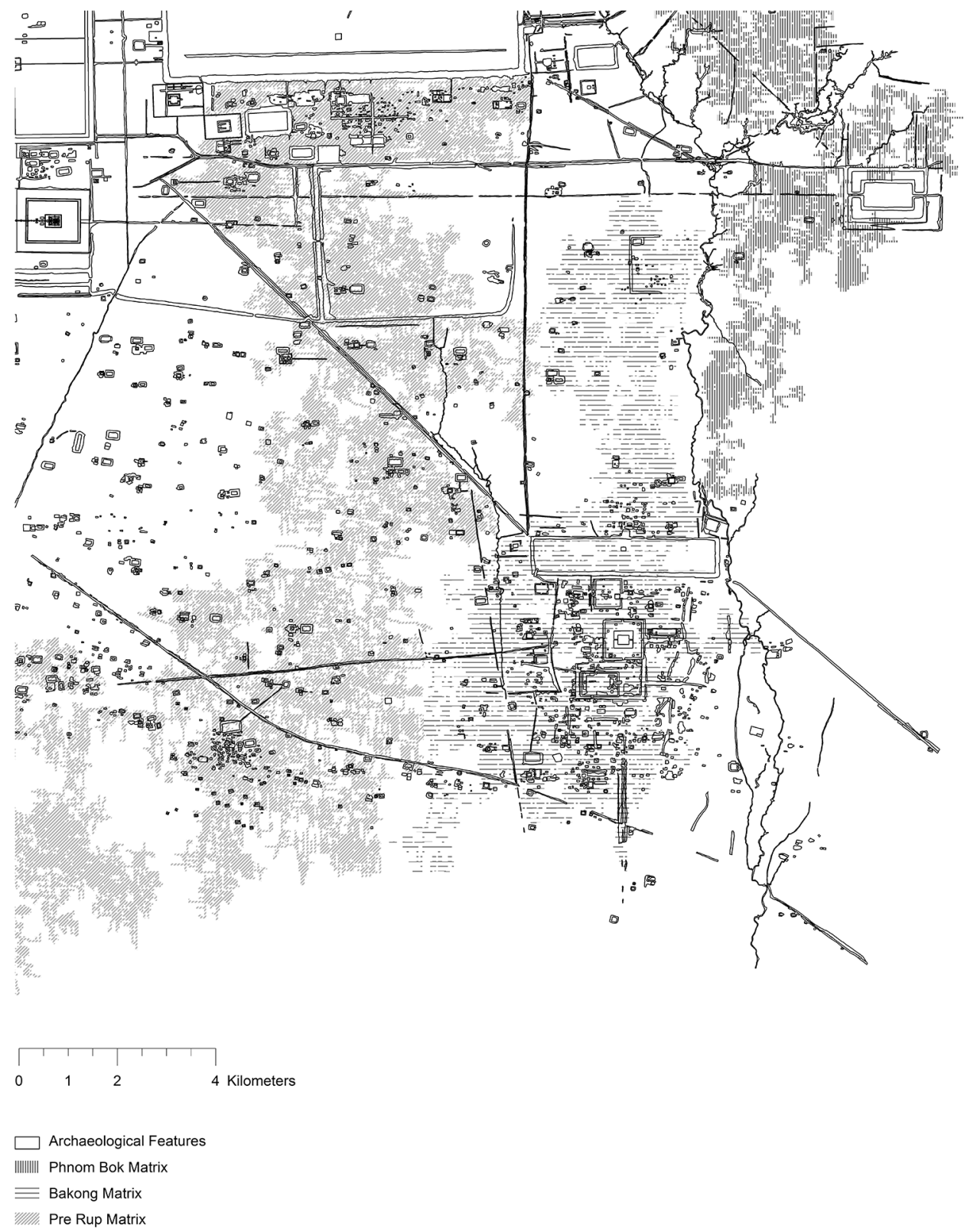

Fig. 4. Cardinal rice-field matrices at the metropolitan scale. The cardinal landscapes of both local and state temples form a series of contiguous patches that coalesce into elongated matrices of cardinal fields. (Data sources: Evans 2007; Hawken 2011; Pottier 1999.)

Pandanus humilis (romchek) and Calamus salicifolius (rompeak). These hedges create outdoor "rooms" within the landscape that appear clearly in aerial photographs and satellite and radar images. Such "rooms" are especially apparent in images of the area northwest of the West Baray. Gourou $(1940,1983)$ was critical of this approach to 


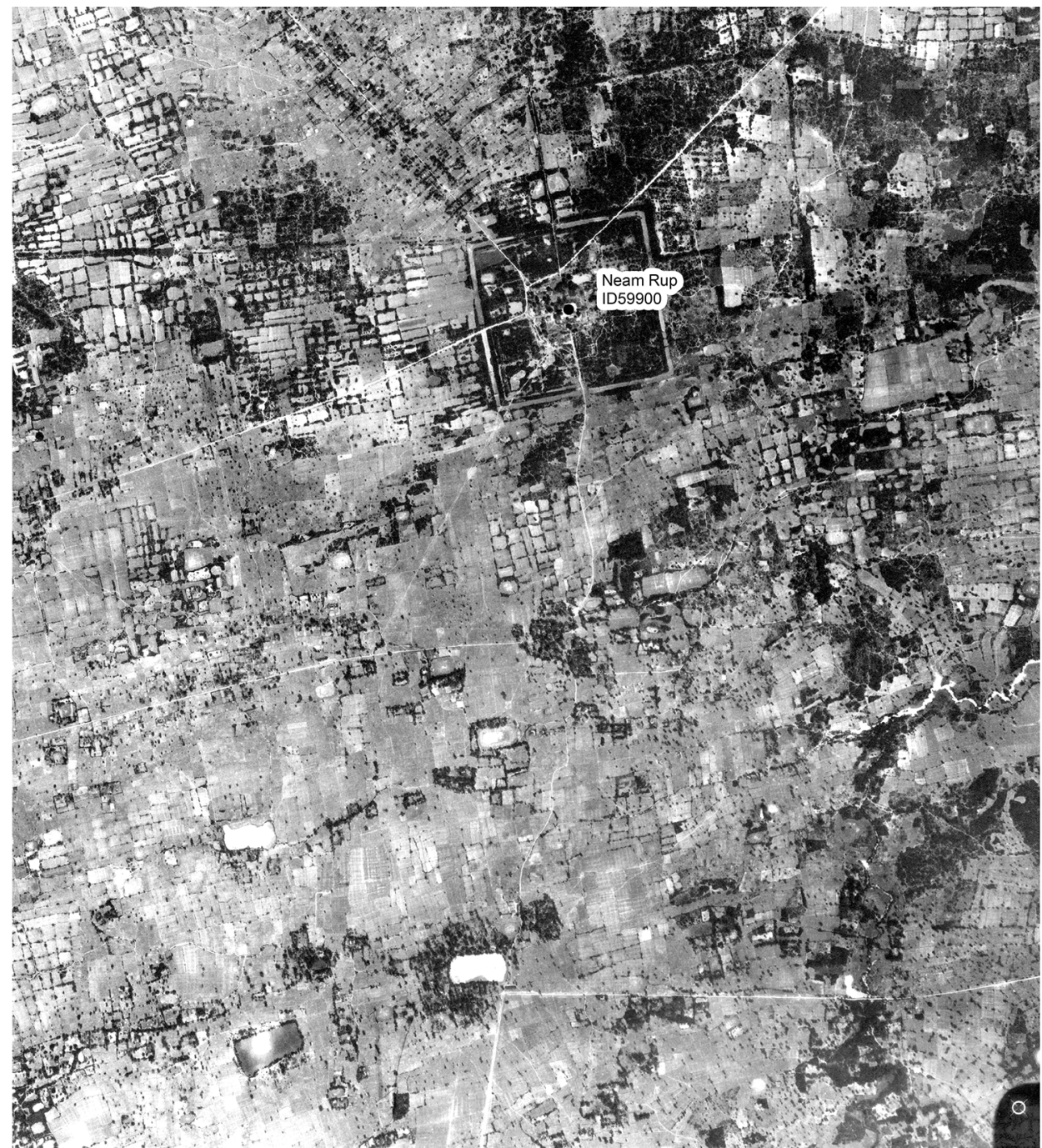

500

1.000

2.000 Meters

Fig. 5. Coaxial rice-field systems to the northwest of Greater Angkor. The presence of a dense, repetitive pattern of small obliquely aligned ponds characterizes the most coherent parts of the system. (Base map: $1:$ 25,000-scale. Finnmap 1992 stereoscopic coverage, band 31, nos. 2060 and 2061.)

agriculture, thinking it wasteful of space. However, when one visits the area today, it is obvious that these large hedges offer valuable protection against wandering animals, and act as living storehouses for crafts products, construction, and alimentation.

Such coaxial systems extend across much of northwest Angkor, their azimuths making angles of between $51^{\circ}$ and $84^{\circ}$ (see Fig. 5). Although patches of this coaxial system are present near the $30 \mathrm{~m}$ contour, the system only really exists as a matrix south of the $20 \mathrm{~m}$ contour. Coaxial systems occur both north and south of the West 
Baray, and have the same range of orientations in both locales. A regional analysis suggests both north and south coaxial systems form part of the same system. The size of their fields, their orientation, and their association with numerous similarly aligned trapeang and prasat all support this idea (Fig. 6).

Furthermore, the regular orientation of fields, the regularity of field divisions, the similar scale of these divisions, and the interdependency of rice fields throughout the system all suggest a major phase of continuous construction. The West Baray interrupts the distribution of the system, suggesting that the rice fields were well established before the construction of the West Baray, thereby forming part of the earlier settlement patterns of the area. Morphological variability within the system suggests it developed over an extended period. The scale of the system surpasses the grids associated with Rajendravarman I's and Yasovarman I's royal complexes (Pottier 1999).

Unlike the massive infrastructure and consistent division that characterizes the royal landscapes within the central urban area of Greater Angkor, the development of the western coaxial rice-field system seems to have been incremental and unspectacular. The consistent yet subtly inflected approach to the division of land throughout the system and its lack of large infrastructure provide strong evidence of locally determined development, based on traditional material behavior rather than development directed by kings and elites. The southern limit of the coaxial matrix lies near Kok Svay Thom ID51100 and Wat Ampil ID100565, where, in relation to a change in the landscape's aspect, the orientation of many rice fields alters from west toward the southwest.

Most of the archaeological features aligned with the coaxial system are ponds or small local temples exhibiting no epigraphy or diagnostic architectural remains. Ponds and local temples are inserted into the context of the rice-field system. Unlike the cardinal systems previously discussed, they do not generate their own rice-field grids. Here, the rice fields form the generative system for the landscape, rather than institutions such as state temples and hydraulic infrastructure. There are some larger structures aligned with the coaxial system that inform us about the development of the system, however. One such structure is Prasat Neam Rup, discussed below.

\section{Neam Rup: An Angkorian Refurbishment of a Coaxial Landscape}

The complex of Neam Rup ID59900 presents a morphological case study of the transformation of coaxial landscapes by later construction. Neam Rup is a large temple complex to the north of the West Baray (Fig. 7). Today, its three sandstone towers are in ruins. However, there are enough remains to suggest that this was once a significant, even opulent, establishment. Sandstone carvings and statue fragments lie scattered and in piles throughout the complex. A modern wat (Buddhist monastery) sits at the site's center. The inner sanctum of the complex is ringed by a horseshoeshaped moat of Angkorian proportions that can be crossed via two causeways, one to the east and one to the west. Surrounding this moat are two concentric embankments, which are in turn enclosed by a rectangular moat measuring $600 \mathrm{~m} \times 565 \mathrm{~m}$. This second moat encloses an area of about 30 ha. Within the enclosure there is a series of causeways organized in a grid. The two primary causeways that extend from within the inner sanctum each make an angle of $77^{\circ}$ with the north-south azimuth. The various components of the complex are not arranged precisely at right angles with each other but diverge by a few degrees. Beyond the outer moat, several other 

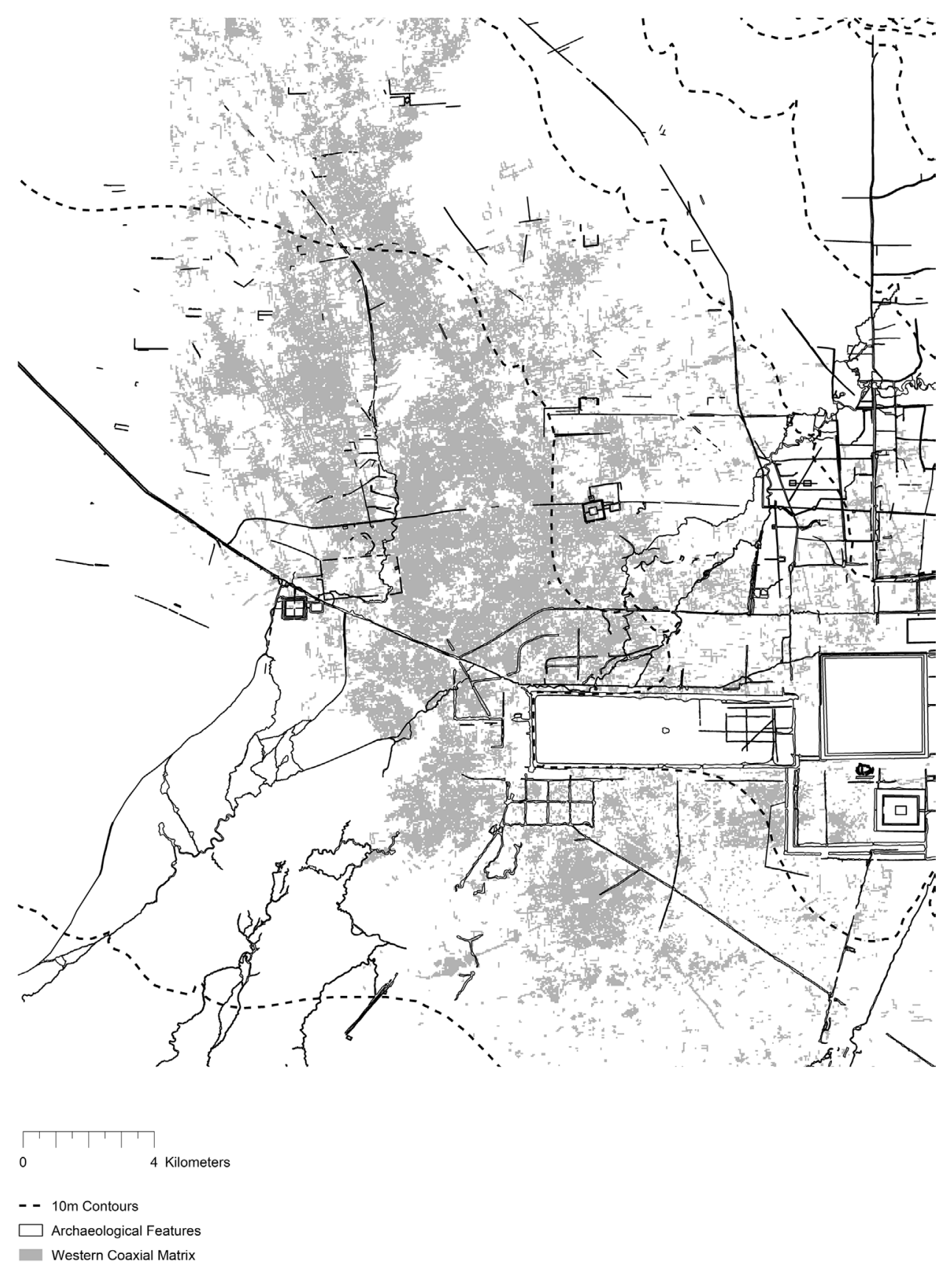

Fig. 6. Western Angkor coaxial system. In contrast to central Angkor, coaxial rice-field systems dominate the landscapes at the periphery of Greater Angkor. (Data sources: Evans 2007; Hawken 2011; Pottier 1999.) 


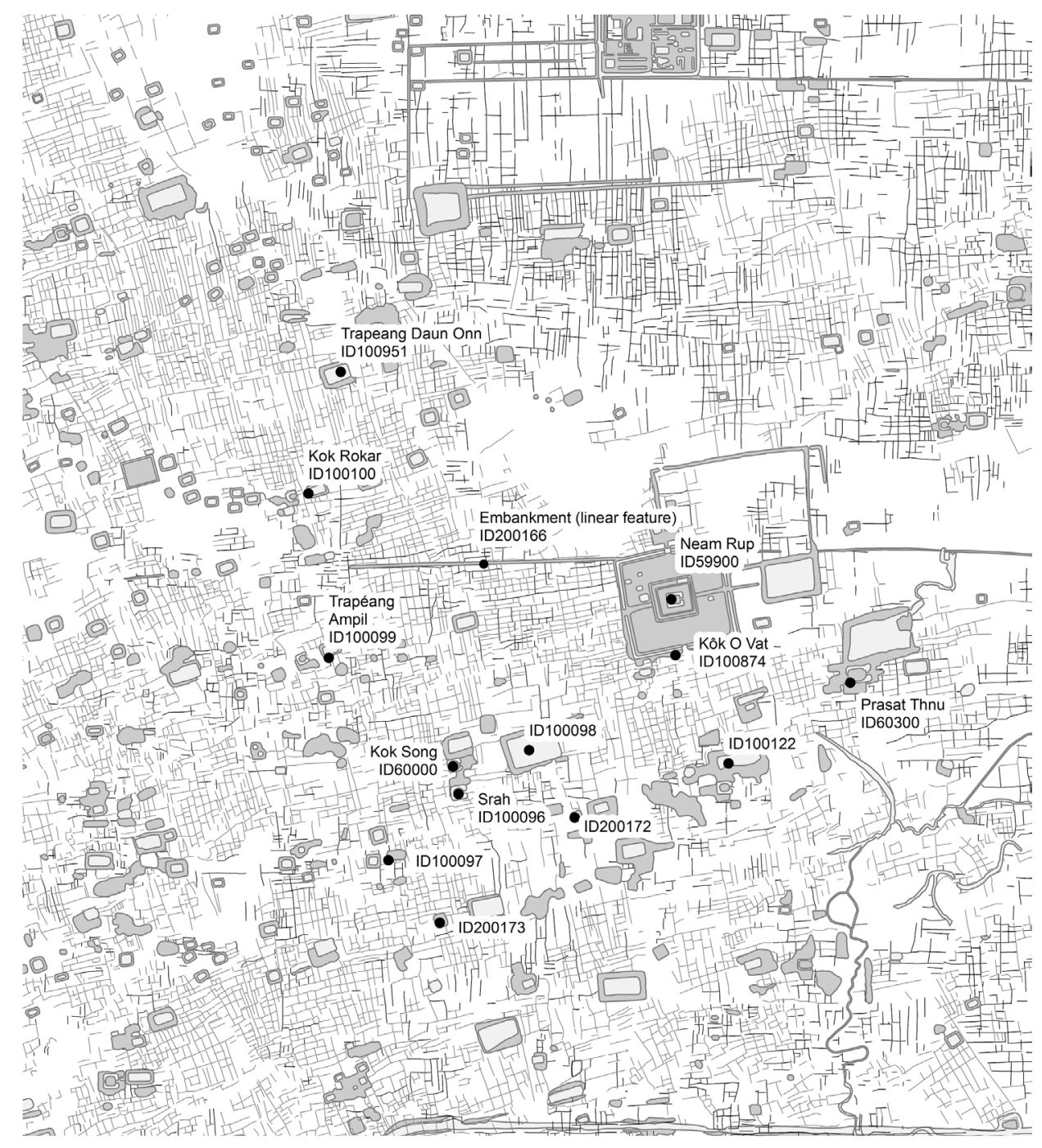

$0 \quad 500 \quad 1,000 \quad 2,000$ Meters

\section{- Site ID}

Coaxial Rice-field System

_ Orthogonal Rice-field System

$\square$ Pond, Moat or Reservoir

Embankment, Mound or Temple Site

Fig. 7. Neam Rup complex. Neam Rup is a large temple complex to the north of the West Baray. The complex is a cumulative palimpsest that contains preexisting coaxial rice-field systems that have been modified in a process of separate interventions by different landowners. (Data sources: Evans 2007; Hawken 2011; Pottier 1999.) 
pieces of infrastructure are integrated with the site in a way that suggests Neam Rup is a multiphase palimpsest rather than a single-phase development.

Architectural material found at Neam Rup and inscriptions such as the one found near Neam Rup at Daun Onn ID100951 suggest twelfth-century A.D. dates (Aymonier 1901:380). Pottier (pers. comm. 2010) suggests that the early twelfth-century Daun Onn inscription K. 254 (Cœdès 1951) probably originates from Neam Rup. The Daun Onn inscription provides a snapshot of the economic functioning of the temple and a revealing description of construction undertaken during the twelfth century (Cœdès 1951:180-192). The inscription gives a glimpse of the sociopolitical power play involved in maintaining the landscapes of Greater Angkor.

According to the inscription, the land of the Neam Rup estate was divided into socioeconomic portions. There was a "common field of the cult" from which the harvest went to the temple, a "field of the servants of the cult," and also a "field of the chief priest" to supply the temple's elites. And, finally, there were "sustenance fields" to supply the temple's indentured laborers (knum). The temple's knum were divided into two groups; each group worked the "field of the cult" for half a lunar month and their "fields of sustenance" for the rest of the month. The recorded quantity of the harvest from the "field of the cult" - that is, for the temple-is lower than the recorded quantity slated for sacrifice in the temple. It is possible that the difference was made up with produce from other lands and by bequests, or that there were two harvests per year ( Lustig 2001:A17-A18; Sedov 1963:74). Scholars speculate that a local temple may have been required to supply a central temple with a significant portion of its rice as state revenue (Lustig $2001: 27$ ).

The Daun Onn inscription provides a compelling picture of the physical transformation of the landscape surrounding Neam Rup. The temple was built by a Brahman who served successive kings. Since the Brahman was the king's chief herdsman, he was able to accumulate enough wealth to purchase land at Neam Rup, establish a religious foundation there, and pay for all the other things associated with such an establishment, including servants, food, clothes, rice fields, and rituals. Because the land for the temple was purchased, not claimed from the forest (as is often mentioned in inscriptions concerning the establishment of temples), we know that the Neam Rup complex had already been settled and cultivated by the early twelfth century (Cœdès 1951:191). The inscription describes the period from A.D. 1095 to 1126, during which shrines dedicated to Shiva and Vishnu, a moat, walls, fences, and ornamental ponds were all constructed.

The author of the Daun Onn inscription conspicuously omits any claims of lineage. Claims establishing a historical familial right to a territory or a title are the norm among inscriptions at Angkor (Ricklefs 1967:419), and temples and religious foundations were important means by which elites enhanced their legitimacy (Lustig 2009: 53). That the numerous structures at Neam Rup as yet lack statements of lineage suggests that a hereditary right to the land was probably nonexistent, so the temple's founder may have invested in symbolic architectural and landscape structures to legitimize the transfer of land.

This extensive construction on already established rice-field landscapes provokes a closer look at the chronological information embedded within the morphology of the landscape. In some ways Neam Rup is well integrated into its context of coaxial rice fields, but in other ways it is very clearly a separate domain. Two grids extend from the outer moat of Neam Rup. The first extends west for several kilometers in long, 
$30 \mathrm{~m}$ wide strips of fields until arriving at a small trapeang. The second grid, which consists of square fields that are each about $45 \mathrm{~m}$ wide, extends south to Prasat Thnu ID60300. The boundaries of these grids are each visible as a change in the regularity of rice fields. However, the two grids are well aligned with the surrounding landscape, each having a very similar morphology to that landscape. This suggests that the preexisting rice fields surrounding Neam Rup were formalized during the works described in inscription K. 254.

A linear feature (ID200166) cuts across the coaxial rice-field system that surrounds Neam Reap, suggesting that the feature postdates the coaxial fields. However, the concentric embankments within the Neam Rup complex are superimposed upon the linear feature, which suggests the feature was constructed before the renovation of Neam Rup.

The Neam Rup complex is a cumulative palimpsest that has adapted preexisting coaxial rice-field systems, most likely created through local incremental development in a process of separate interventions by elite landowners. Even though we know these systems were built before the twelfth century, to better define their age we need to look to prosaic archaeological features, such as ponds and local temples, that are more cohesively embedded within the coaxial rice-field systems. This will help clarify the development phases of the landscape and its relation to large temple complexes such as Neam Rup. These small local features appear to have been built within the same phase of construction as the large coaxial system: they are difficult to date because they are devoid of diagnostic elements such as inscriptions and distinctive architectural features. A systematic archaeological survey of everyday landscape features is needed to provide more information on the chronology of coaxial systems.

\section{RICE FIELDS AND THE SPATIAL ECONOMY}

Pottier (1999: 119) suggests a useful topographic classification of temples and rice fields:

Elles peuvent être réparties en deux catégories en fonction de l'origine de leur orientation : certaines masses sont à l'évidence générées par un sanctuaire orienté assez exactement à l'Est et suivent l'orientation de celui-ci, les autres montrent une adaptation essentiellement topographique.

Such a typology is demonstrated by current systematic approaches to analysis and classification of the landscape. To explain the above quotation using the terminology of this article: cardinal systems belong to the first type, where a cardinal temple generates a patch of cardinally oriented fields around it. Coaxial systems belong to the second type, where rice fields form a large, topographically sensitive matrix in which other elements are inserted. Extensive mapping undertaken as part of this study gives such statements a geographic resolution. We now know where these system types occur in the landscape, and can begin to suggest why they occur at such locations.

Cardinal networks are strongly related to centrality: their geometry embodies power. Cardinal rice-field networks are also strongly associated with local temples, so it seems they were frequently institutional landscapes. The location of cardinal systems on productive stream alignments is also evidence that such systems represent centralized power.

It follows that coaxial systems are indicative of land having been organized at a local level, perhaps according to a system of collective ownership. If this was indeed the 
case, then appropriating the wealth of Greater Angkor's periphery would have presented an interesting challenge for central elites. Temple institutions installed into the peripheral landscape were probably too broadly dispersed for efficient, direct management by the state. Rent collection and sharecropping were probably more viable means of extracting income from the inhabitants of the diffuse periphery (Trigger $2003: 315-337)$.

This classification also contributes to our conception of the landscape structure of the Angkorian and pre-Angkorian periods. Cardinal systems are often found in association with formal settlement complexes and large hydraulic infrastructure established by Angkorian elites. By contrast, coaxial systems are often distinguished by a repetitive pattern of small, similarly aligned local temples and ponds, possibly constructed through more incremental processes accessible to local communities without direct intervention from the state. The lack of tight integration with state infrastructure and spatial administration raises the possibility that the coaxial system originated before the superstructure of the Angkorian state.

This first systematic analysis of field systems in the context of urban development in Southeast Asia suggests the importance of land division as a source of economic information in its own right. It is a vigorous approach to understanding societies from the bottom up rather than the more conventional top down approach implicit in epigraphic and art historical studies. Furthermore, this analysis of the total landscape demonstrates the importance of examining high-resolution, remote-sensing imagery of medieval Southeast Asian landscapes to gain a more complete understanding of cities and their societies.

\section{ACKNOWLEDGMENTS}

The author would like to acknowledge the Greater Angkor Project, and its members, which formed the scholarly context for the research contained within the article. The Greater Angkor Project is a multinational collaborative research project between French, Cambodian, and Australian researchers, but is primarily based at the University of Sydney in New South Wales, Australia. All three of the partner institutions in the Greater Angkor Project (APSARA, EFEO, University of Sydney) contribute directors to the project, as well as a range of other staff across many different disciplines

\section{REFERENCES CITED}

Aymonier, E.

1901 Le Cambodge: Les provinces siamoises. Paris: Ernest Leroux.

BÂTY, P.

2005 Extension de l'aéroport de Siem Reap 2004: Rapport de fouille archéologique. Siem Reap/Paris: APSARA/ INRAP.

Chouquer, G.

2000 L'Étude des paysages: Essais sur leurs formes et leur histoire. Paris: Editions Errance.

Chouquer, G., M. Clavel-Lévêque, F. Favory, and P. Vallat

1987 Structures agraires en Italie centro-méridionale: Cadastres et paysages ruraux. Roma: Ecole Française de Rome.

Chouquer, G., F. Favory, and P. Poupet

1991 Les paysages de l'antiquité: Terres et cadastres de l'Occident Romain. Paris: Errance.

Ccedès, G.

1951 Inscriptions du Cambodge, vol. 3. Paris: E. de Boccard, École française d'Extrême-Orient.

1966 Inscriptions du Cambodge, vol. 7. Paris: E. de Boccard, École française d'Extrême-Orient. 
DAGENS, B.

2003 Les Khmers. Paris: Les Belles Lettres.

Evans, D.

2007 Putting Angkor on the Map: A New Survey of a Khmer "Hydraulic City" in Historical and Theoretical Context. Ph.D. diss. Department of Archaeology, University of Sydney.

Evans, D., C. Pottier, R. Fletcher, S. Hensley, I. Tapley, A. Milne, and M. Barbetti

2007 A comprehensive archaeological map of the world's largest preindustrial settlement complex at Angkor, Cambodia. Proceedings of the National Academy of Sciences 104(36) :14277-14282.

Evans, D., And A. Traviglia

2012 Uncovering Angkor: Integrated remote sensing applications in the archaeology of early Cambodia. In Satellite Remote Sensing: 197-230, ed. R. Lasaponara and N. Masini. Dordrecht: Springer Netherlands.

FLEMING, A.

1987 Coaxial field systems: Some questions of time and space. Antiquity 61(232): 188-202.

1989 The genesis of coaxial field systems. In What's New?: A Closer Look at the Process of Innovation: 63-81, ed. S. Ernst van der Leeuw and R. Torrence. London: Unwin Hyman.

FLETCHER, R.

2009 Low density, agrarian-based urbanism: A comparative view. Insights 2(4):1-19.

Goloubew, V.

1936 Reconnaissances aériennes au Cambodge. Bulletin de l'École française d'Extrême-Orient $36(2): 465-478$.

Gourou, P.

1940 L'utilisation du sol en Indochine Française. Paris: Hartmann.

1983 Land Utilization in French Indochina. New York: Institute of Pacific Relations.

Groslier, B.-P.

1952 L'avion et l'archéologie indochinoise. Forces aériennes françaises. 67:51-83.

1974 Agriculture et religion dans l'Empire angkorien. Études rurales 53-56:95-117.

1979 La Cité hydraulique angkorienne: Exploitation ou surexploitation du sol? Bulletin de l'École française d'Extrême-Orient 66:161-202.

1998 Le passé vu du ciel. In Mélanges sur l'archéologie du Cambodge (1949-1986). Paris: École [1956] française d'Extrême-Orient.

HAWKEN, S.

2011 Metropolis of Ricefields: A Topographic Classification of a Dispersed Urban Complex. Ph.D. diss. Department of Archaeology, University of Sydney.

JOHNSTON, R.

2005 Pattern without a plan: Rethinking the bronze age coaxial field systems on Dartmoor, South England. Oxford Journal of Archaeology 24(1): 1-21.

LUNET DE LAJONQUière, E.

1902 Inventaire déscriptif des monuments du Cambodge. 3 vols. Paris: École française d'Extrême-Orient.

Lustig, E.

2001 Water and the Transformation of Power at Angkor, 10th to 13th Centuries A.D. Honours diss. Department of Prehistoric and Historic Archaeology, University of Sydney.

2009 Power and Pragmatism in the Political Economy of Angkor. Ph.D. diss. Department of Archaeology, University of Sydney.

MARCHAL, H.

1931 J Journaux de fouilles de la Conservation d'Angkor (Fév). Siem Reap: École française d'ExtrêmeOrient.

1931 bournaux de fouilles de la Conservation d'Angkor (Mars). Siem Reap: École française d'ExtrêmeOrient.

Martin, M.

1981 La rizicutlure et la maitrise de l'eau dans le Kamphuchea démocratique. Études Rurales $83: 7-44$.

McGarigal, K., S. A. Cushman, M. C. Neel, and E. Ene

2002 FRAGSTATS: Spatial Pattern Analysis Program for Categorical Maps. Available at: http://www. umass.edu/landeco/research/fragstats/fragstats.html [accessed 4 August, 2010]. 
PotTier, C.

1993 Préparation d'une carte archéologique de la région d'Angkor. Mémoire de DEA. Sorbonne Nouvelle, Paris III.

1999 Carte archéologique de la région d'Angkor, Zone Sud. Ph.D. diss., 3 vols. UFR Orient et Monde Arabe, Sorbonne Nouvelle, Paris III.

$2000 a$ À la recherche de Goloupura. Bulletin de l'École française d'Extrême-Orient 87:79-107.

$2000 \mathrm{~b}$ Some evidence of an inter-relationship between hydraulic features and rice field patterns at Angkor during ancient times. The Journal of Sophia Asian Studies 18:99-120.

2003 Yasovarman's Buddhist asrama in The Buddhist Monastery: A Cross Cultural Survey: 199-208, ed. Pierre Pichard and François Lagirarde. Paris: École française d'Extrême-Orient.

RICKLEFS, M.

1967 Land and law in the epigraphy of tenth-century Cambodia. Journal of Asian Studies 26(3): 411-420.

SEDOV, L.

1963 On the problem of the economic system in Angkor, Cambodia in the ninth-twelfth centuries. Narody Asii I Afriki, Istoria, Ekonomika, Kul'tura 6:73-81.

Traviglia, A.

2010 The lost rivers of Angkor: Insights from remote sensing and DTM data. Unpub. paper presented at the Angkor Research Symposium, École française d'Extrême-Orient Siem Reap.

Trigger, B. G.

2003 Understanding Early Civilizations: A Comparative Study. Cambridge: Cambridge University Press.

Turner, M. G.

2005 Landscape ecology: What is the state of the science? Annual Review of Ecology, Evolution, and Systematics 36:319-344.

VAN Liere, W.

1980 Traditional water management in the lower Mekong Basin. World Archaeology 11(3) :265-280.

1989 Mon-Khmer approaches to the environment, in Culture and Environment in Thailand: $A$ Symposium of the Siam Society: 142-160, ed. Siam Society. Bangkok: The Siam Society.

\begin{abstract}
Greater Angkor was the capital of the Khmer Empire from the ninth to the fourteenth centuries A.D. The rulers of Angkor left behind magnificent temples, along with extensive, centrally planned landscapes and massive urban complexes. However, the landscape of Greater Angkor also represents a decentralized planning tradition. This article addresses the different scales of economic landscapes at Greater Angkor: from massive ricefield superstructures watered by artificial irrigation, to smaller patches of fields organized around local temples and ponds. Contrary to widely accepted views, the design of extensive cultural landscapes does not require the presence of an elite controlling authority, or the guidance of a commonly conceived plan. Within Greater Angkor, the design of extensive landscapes often occurred at the local level, most likely involving local traditions rather than abstract, centrally approved plans. The relationship between centralized and decentralized planning traditions is investigated using a topographic classification of the landscape based on extensive mapping from remote sensed imagery from 20072010. Covering $1000 \mathrm{~km}^{2}$ of rice fields, and including $22,000 \mathrm{~km}$ of rice-field bunds, the topographic classification of the rice-field systems reveals two very different ways of building. These two systems are best described as coaxial systems and cardinal systems: both suggest dramatically different development models and socioeconomic frameworks. The two different, and extensive, development processes had a lasting physical impact on the resulting landscapes, and are still actively used today. This article discusses the evidence for both central and local plans as well as more complicated examples, where both central and local plans seem to have influenced the design of landscapes. Illustrated examples of centrally planned landscapes and local approaches to planning landscapes demonstrate this premise. KeYwords: Greater Angkor, urban landscape, Khmer studies, landscape archaeology, archaeological rice fields, cultural landscapes, archaeology, coaxial field systems, cardinal field systems, radial field systems, landscape morphology, GIS, remote sensing, Angkorian land use, land division systems.
\end{abstract}

